\title{
Change of Attitude, Behaviour in Choosing Healthy Snacks Through Health Education with Educative Game Media of Monopoly About Healthy Snacks for Children of School Age
}

\author{
Eni Sumarliyah ${ }^{1}$, Aries Chandra Anandita ${ }^{1}$, Dede Nasrullah ${ }^{1 *}$, Rizaldi Heru Susanto ${ }^{1}$
}

${ }^{1}$ Faculty Health of Science University Muhammadiyah of Surabaya, Surabaya, Indonesia

*Corresponding author. Email: dedenasrullah@um-surabaya.ac.id

\begin{abstract}
Choosing unhealthy food is one of problems that occur to many children. Choosing snacks that are not in health standards would cause health problems. The purpose of this study identified change of attitude, behavioural in choosing healthy snacks through health education with the educative game media of monopoly about healthy snacks for children of school age. This study used the Quays Experimental Design (Pre-testPost-test with control group design) with 140 samples in elementary school in Surabaya. Data were analysed using Wilcoxon Sign Rank Test and Mann Whitney U Test with a significance level of $\leq 0.05$. The results showed that there was a change of positive attitude $86 \%$ with $p=0.000$, while the behaviour was $69 \%$ behaving well and the results of statistical tests $p=0.000$. This was because they had good experience through games that were fun, as well as teacher support and available facilities. Thus, the experience through health education by using monopoly about healthy snacks that could change the behaviour of choosing healthy snacks for children of school age to reduce and prevent the occurrence of disease.
\end{abstract}

Keywords: healthy snacks, educative game, children of school age, monopoly, attitude, behaviour

\section{INTRODUCTION}

School-age children have the habit of buying snacks outside the home. The habit of buying snacks makes them rarely to have breakfast at home and ask for pocket money to buy snacks instead. This has an impact on the child's diet, which is generally when hungry children prefer to buy snacks to just fill the stomach. Data shows that only $99 \%$ of school children have a habit of buying snacks around schools [1]. On average they buy twice a day when school breaks [2]. Research in Bogor in 2009 said school-age children consumed 6-7 types of snacks per week [3]. Snacking habits that are too often can indirectly reduce the child's appetite. Currently there are still many snacks that do not meet food safety requirements so that they can endanger children's health [4].

Based on data from Extraordinary Events (KLB) on schoolchildren snacks in 2008-2012, elementary school students (SD) were the group most frequently experienced food poisoning [5]. In East Java, it is not much different from other regions, namely the large number of mobile food vendors who do not guarantee the hygiene and safety of the food they sell. The coverage of networking and health services for elementary and equivalent students in East Java Province in 2013 was $57.25 \%$, of course this figure had not reached the expected target [5]. The cause of illness due to snacks in school-age children in 2014 was the highest due to microbial pollution by $74.9 \%$, excess food additives by $9 \%$ and use of hazardous materials $15.7 \%$ [1]. Four types of snacks for schoolchildren who did not meet the requirements in Indonesia in 2014 were ice drinks, coloured drinks and syrup, meatballs and jelly [1]. A person's habits relate to personal characteristics and environmental factors. In this case, the environment that most influences the healthy snack behaviour of children is the family and the environment at school. Habits and patterns of behaviour that are created among school-age children are strongly influenced by peers, including behaviour to consume snacks at school [6].

Snacking schoolchildren who are not guaranteed health can potentially cause poisoning, indigestion and if it lasts long it will cause poor nutritional status. In addition, unhealthy snacks can also disrupt children's performance in school [7]. Dangerous snacks are packaged, their shape and colour are very popular with school-age children so that many children consume them without knowing the dangers and consequences that can arise from these snacks. The misuse of addictive substances that are put in excess into snacks is very dangerous. This indeed will not be seen in the near term but in the long term there will be damage to the kidneys and disorders in the child's body. Any snack can make and cause a child to become diarrhoea, food ingredients that are carcinogenic can cause cancer and tumours. Other impacts caused are uncontrolled obesity, nausea and vomiting poisoning[8].

In addition, the occurrence of food-borne diseases or foodborne diseases is a result of unhealthy snacking behaviour. In general, foodborne diseases are a public health problem that is less Changing Unlimited Snacks Behaviour, preferably in many countries, because this 
disease is considered not a serious disease. In fact, this case is often not reported. This disease is usually toxic and infectious, caused by disease agents that enter the body through consumption of contaminated food [9].

\section{METHOD}

The research design used in this study is Quays Experimental design (pre-test - post-test control group design), which is a research design that seeks to reveal causal relationships by involving the control group in addition to the experimental group [10]. The sampling technique used is by using purposive sampling. The sample used in this study was elementary school students in Surabaya with 140 respondents. Data is processed using the Wilcoxon Sign Rank Test and Mann Whitney U Test with a significance level of $\leq 0.05$.

\section{RESULTS AND DISCUSSION}

\subsection{Identification of Healthy Snacks Choosing Before and After Healthy Health Monopoly Health Education in Treatment and Control Groups in Elementary Students in Surabaya}

Respondent data when pre-test in the treatment group $86 \%$ were negative, while in the post-test $86 \%$ were positive. Based on Table 1 shows that the results of the research attitudes of respondents before being given health education interventions through the media of healthy snacks monopoly mostly have a negative attitude that is as much as 60 respondents $(86 \%)$ in the treatment group and $58(83 \%)$ respondents in the control group. While after treatment almost all of them had a positive attitude, namely 60 respondents $(86 \%)$ and in the control group 56 respondents in the control group (80\%).

Table 1 Attitudes of healthy snacks selection before and after health healthy monopoly health education in the treatment and control groups in Surabaya elementary school students

\begin{tabular}{|lcccccccc|}
\hline & Treatment & \multicolumn{9}{c}{ Control } & & Post test \\
\cline { 2 - 9 } & Pre-test & Post test & Pre-test & \multicolumn{1}{c|}{} \\
\hline & $\mathrm{f}$ & $\%$ & $\mathrm{f}$ & $\%$ & $\mathrm{f}$ & $\%$ & $\mathrm{f}$ & $\%$ \\
Positive & 10 & 14 & 60 & 86 & 12 & 17 & 14 & 20 \\
Negative & 60 & 86 & 10 & 14 & 58 & 83 & 56 & 80 \\
\hline Total & 70 & 100 & 70 & 100 & 70 & 100 & 70 & 100 \\
\hline
\end{tabular}

Many things are influential in this regard, including the influence of the environment both formally and informally. Attitudes are formed when someone has gained knowledge and by the interaction experienced by individuals. Interaction is not just contact and relationships between individuals as group members. In interaction there is a relationship of mutual influence between individuals with each other [11]. After someone knows the stimulus / object, the next process will assess or behave towards the stimulus or object of the health process. Therefore, Indicators for health attitudes are also in line with knowledge about health. Positive knowledge can make someone be positive or negative[12]. In addition attitudes are also influenced by physiological factors (age, health), direct experience of the object of attitudes, factors of reference, and social communication [13]. Primary school age is a young age so it is less mature in seeing problems. In addition, they also have not had a lot of experience with real objects, as well as information that is still lacking.

\subsection{Identification of Healthy Snacks Selection Behaviour Before and After Given Healthy Snack Monopoly Health Education in Treatment and Control Groups in Surabaya Elementary School Students}

Based on table 2 shows that the results of the respondents' action research before being given a health education intervention through the game media healthy snacks monopolies from each group both the treatment group and the control group had less action, namely 52 respondents (74\%) in the treatment group and $46(66 \%)$ in the control group. Whereas after the treatment the treatment group had a good action as many as 48 respondents $(69 \%)$. Whereas in the treatment group $32(46 \%)$ is sufficient.

Table 2 Behavioural selection of healthy snacks before and after given healthy snack monopoly health education in treatment and control groups in Surabaya elementary School Students

\begin{tabular}{|lcccccccc|}
\hline & Treatment & \multicolumn{3}{c}{ Control } & \multicolumn{3}{c|}{ Post test } \\
\cline { 2 - 9 } & Pre test & Post test & Pre test & \multicolumn{1}{c|}{} \\
\hline & $\mathrm{f}$ & $\%$ & $\mathrm{f}$ & $\%$ & $\mathrm{f}$ & $\%$ & $\mathrm{f}$ & $\%$ \\
Good & 6 & 9 & 48 & 69 & 8 & 11 & 10 & 14 \\
Enough & 12 & 17 & 20 & 28 & 16 & 23 & 32 & 46 \\
Less & 52 & 74 & 2 & 3 & 46 & 66 & 28 & 40 \\
\hline Total & 70 & 100 & 70 & 100 & 70 & 100 & 70 & 100 \\
\hline
\end{tabular}


The data showed that in the treatment group when the most pre-test behaved less $74 \%$, while at post-test $69 \%$ behaved positively. Practice is the third domain of behaviour after knowledge and attitude [12]. After knowing the stimulus or object, then making an assessment or opinion on what is known (attitude), then someone is expected to be able to implement, practice or have the ability to practice what is known and addressed. Knowledge or cognitive is a domain that is very important for the formation of one's actions [12].

\subsection{Analysis of the Effect of Health Education through Media Healthy Monopoly Games on Attitudes to Choosing Healthy Snacks of Elementary Students in Surabaya}

Wilcoxon Signed Rank Test statistical test results in the treatment group is $\rho=0.000<\alpha=0.05$, while in the control group is $\rho=0.317>\alpha=0.05$. The Mann U Whitney test results obtained $\rho=0.000<\alpha=0.05$. Based on the results of the statistical test of wilcoxon signed ranks test obtained the significance value of pre-post in the treatment group was $p=0,000$ so that it was smaller than the alpha value $(<0.05)$. This means that $\mathrm{H} 0$ is rejected and $\mathrm{H} 1$ is accepted, meaning that there is an influence of health education through the media playing a healthy snack monopoly on increasing attitudes in choosing healthy snacks for elementary students in Surabaya. Whereas in the control group obtained the significance value of $\mathrm{p}=0.080$ so that it is greater than the alpha value $(>0.05)$. This means that $\mathrm{H} 0$ is accepted and it can be concluded that there is no effect of health education through the media of healthy snacks monopoly on increasing attitudes in choosing healthy snacks for elementary students in Surabaya in the control group. And the Mann U Whitney test results showed $p$ value $=0,000<\alpha$ $=0,05$ so there was a difference between the attitude of the treatment group given health education media healthy snacks monopoly with the control group without being given health education media healthy snacks monopoly.

Table 3 Influence of health education through media monopoly games for healthy snacks against attitude choosing healthy snacks of elementary students in Surabaya

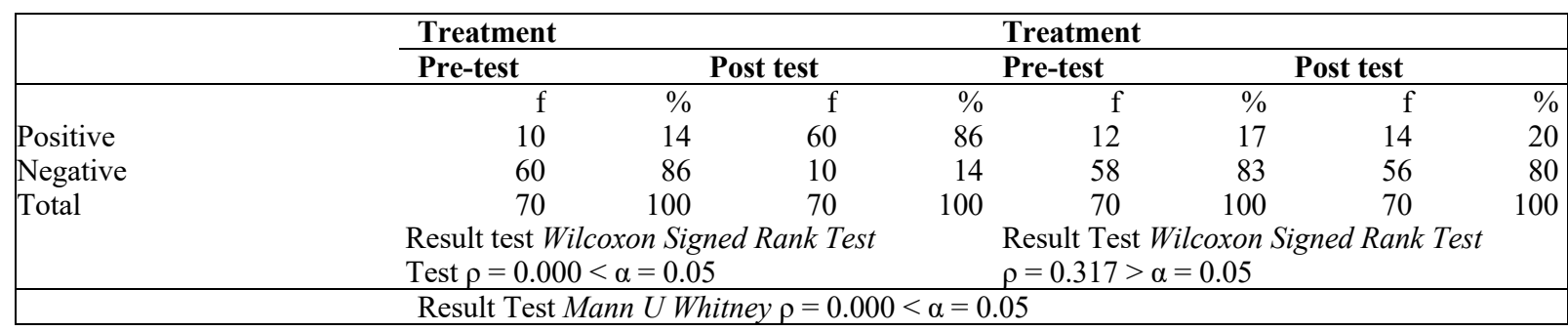

An increase in the attitude of respondents after health education interventions through educational media, healthy snacks monopoly is caused by the experience gained during playing healthy snacks monopoly educational games. The experience of choosing healthy snacks is strengthened by the simulations that exist in the healthy snack's monopoly educational game. Learning from simulation of healthy snacks monopoly game tools makes children understand and understand the danger of snacking so that the child responds with an attitude that changes toward the positive. Positive attitudes of children in choosing snacks because of the healthy snacks monopoly educational games there are positive and negative effects of consuming snacks that they will directly get when playing and comparing with reality in children.

\subsection{Analysis of the Effect of Health Education Through Media on Healthy Snack Monopoly Games on Behaviour in Choosing Healthy Snacks of Elementary Students in Surabaya}

The Wilcoxon Signed Rank Test statistical test results in the treatment group is $\rho=0,000$ Wilcoxon Signed Rank Test statistical test results in the treatment group is $\rho=0,000<\alpha$ $=0.05$, while in the control group is $\rho=0.317>\alpha=0.05$. The Mann U Whitney test results obtained $\rho=0,000<\alpha=$ 0.05 .

Table 4 Effect of health education through media on healthy snack monopoly games on behaviour in choosing healthy snacks of elementary students in Surabaya

\begin{tabular}{|c|c|c|c|c|c|c|c|}
\hline & \multicolumn{3}{|l|}{ Treatment } & \multicolumn{4}{|c|}{ Control } \\
\hline & Pre-test & \multicolumn{2}{|c|}{ Post test } & \multicolumn{2}{|c|}{ Pre-test } & \multicolumn{2}{|c|}{ Post test } \\
\hline & $\%$ & $\mathrm{f}$ & $\%$ & $\mathrm{f}$ & $\%$ & $\mathrm{f}$ & $\%$ \\
\hline Good & 9 & 48 & 69 & 8 & 11 & 10 & 14 \\
\hline Enough & 17 & 20 & 28 & 16 & 23 & 32 & 46 \\
\hline Less & 74 & 2 & 3 & 46 & 66 & 28 & 40 \\
\hline \multirow[t]{2}{*}{ Total } & 100 & 70 & 100 & 70 & 100 & 70 & 100 \\
\hline & \multicolumn{3}{|c|}{$\begin{array}{l}\text { Result Test Wilcoxon Signed Rank Test } \\
\text { Test } \rho=0.000<\alpha=0.05\end{array}$} & \multicolumn{4}{|c|}{$\begin{array}{l}\text { Result Test Wilcoxon Signed Rank Test } \\
\rho=0.317>\alpha=0.05\end{array}$} \\
\hline
\end{tabular}


Based on the results of the statistical test of wilcoxon signed ranks test obtained the significance value of pre-post in the treatment group was $\mathrm{p}=0,000$ so that it was smaller than the alpha value $(<0.05)$. This means that $\mathrm{H} 0$ is rejected and $\mathrm{H} 1$ is accepted, meaning that there is an influence of health education through the media playing a healthy snack monopoly on increasing actions in choosing healthy snacks for elementary students in Surabaya. Whereas in the control group obtained the significance value of $p=1,000$ so that it is greater than the alpha value $(>0.05)$. This means that $\mathrm{H} 0$ is accepted and it can be concluded that there is no influence of health education through the media playing a healthy snack monopoly on increasing actions in choosing healthy snacks for elementary students in Surabaya. And the Mann $\mathrm{U}$ Whitney test results showed the value of $\mathrm{p}=0,000<\alpha=$ 0,05 there was a difference between the action (practice) of the treatment group given health education of healthy snacks monopoly with the control group without being given health education media healthy snacks monopoly. With this in mind it can be concluded that there is an effectiveness of the implementation of health education media on healthy snacks monopoly on the actions of students in choosing healthy snacks for elementary students in Surabaya.

Individuals in determining a complete attitude apart from being determined by knowledge, are also influenced by thoughts, beliefs and emotions that play an important role[14]. The individual concerned must be able to absorb, process, and understand the information received as a stimulus. An increase in the attitude of respondents after being given an intervention can be influenced by the knowledge gained from learning and the information contained in the media of healthy snacks monopolies. The attitude aspect of respondents within 3 weeks after being given healthy snacks monopoly intervention has gradually increased through the process of learning activities by giving health education about choosing healthy snacks for school-age children.

A person's actions are influenced by one's knowledge the better the level of respondents, the better in determining decisions in buying healthy snacks [14]. An increase in respondents 'actions in choosing healthy snacks is obtained through the media of healthy snacks monopoly by playing the game and through respondents' questions to measure the value of the respondent's actions before and after the intervention is given.

\section{CONCLUSION}

The attitude of elementary school students in Surabaya in choosing healthy snacks before being given health education through the media of healthy snacks monopoly in the control and treatment groups is mostly negative. Whereas after the action in the treatment group was mostly positive and in the negative control group. The actions of elementary school students in Surabaya in the selection of healthy snacks before being given health education through the medium of healthy snacks monopoly in the control group and treatment are mostly lacking. Whereas after the action in the treatment group was mostly good and the control group was mostly sufficient. There is an influence of health education through the media of healthy snacks monopoly educational games on attitudes of elementary school students in Surabaya. There is an influence of health education through the media of healthy snacks monopoly educational games on the actions of elementary school students in Surabaya.

\section{ACKNOWLEDGMENT}

We gratefully acknowledge the support of the Muhammadiyah University of Surabaya

\section{REFERENCES}

[1] Badan Pengawas Obat dan Makanan (BPOM) RI, Laporan kinerja badan pengawas obat dan makanan R.I tahun 2013. Jakarta: Kepala Badan Pengawas Obat dan Makanan R.I, 2014.

[2] A. Putra, "Gambaran Kebiasaan Jajan Siswa Disekolah," Universitas Diponegoro, 2009.

[3] K. Febriani, "Hubungan asupan energi dengan prestasi belajar remaja di smp pl demonico savio Semarang," Universitas Diponegoro. Semarang, 2013.

[4] E. S.T.C, "Gambaran perilaku jajan murid sekolah dasar di Jakarta," Universitas Atma Jaya Jakarta, 2009.

[5] Departemen Kesehatan RI, "Promosi kesehatan di daerah bermasalah kesehatan," 2013. .

[6] J. Februhartanti, "Amankah makanan jajanan anak sekolah di Indonesia? Serial Online 2008,” 2009. .

[7] F. C. Mora AM, Fernández-ares A, Merelo JJ, García-sánchez P, "Effect of Noisy Fitness in RealTime Strategy Games Player Behaviour Optimisation Using Evolutionary Algorithms," J. Comput. Sci. Technol., vol. 27, no. 5, pp. 1007-1023, 2012.

[8] P. . P. Potter, Buku ajar fundamental keperawatan: konsep, proses dan praktik. Edisi 7 Volume 1. Jakarta: Salemba Medika, 2010.

[9] L. C.-M. Flahive MW, Chuang Y-C, "The Multimedia Piers-Harris Children's Self-Concept Scale 2: Its Psychometric Properties, Equivalence with the Paper-and-Pencil Version, and Respondent Preferences," PLoS One, vol. 10, no. 8, pp. 1-13, 2015.

[10] A. A. A. Hidayat, Metodologi Penelitian Kesehatan. Surabaya: Health Books Publishing, 2010.

[11] S. Azwar, Sikap manusia : Teori dan pengukurannya edisi 2. Yogyakarta: EGC, 2011. 
[14] S. Notoatmodjo, Ilmu perilaku kesehatan. Jakarta: PT. Rineka Cipta, 2010.
[12] S. Notoatmodjo, Promosi kesehatan dan ilmu perilaku Edisi revisi. Jakarta: PT.Rineka Cipta, 2012.

[13] Sunaryo, Psikologi untuk keperawatan. Jakarta: Penerbit Buku Kedokteran, 2015. 